\title{
БУДДИЙСКИЕ ЦЕННОСТИ КАК ВОЗМОЖНАЯ ЭКОНОМИЧЕСКАЯ ДЕТЕРМИНАНТА РАЗВИТИЯ ТУВИНСКОГО ОБЩЕСТВА
}

\author{
Инна С. Тарбастаева \\ Институт философии и права Сибирского \\ отделения Российской академии наук, \\ Российская Федерация
}

\author{
BUDDHIST VALUES \\ AS A POTENTIAL \\ ECONOMIC \\ DETERMINANT \\ IN THE DEVELOPMENT \\ OF TUVAN SOCIETY
}

В статье актуализируется изучение буддийских иенностей в свете их благотворного влияния на социально-экономическое развитие общества Тувы. Этому способствуют имеющиеся научные исследования успешных экономик мира, обзор которых приводится в работе.

После распространения буддизма на Западе в середине ХХ века древние знания и практики стали доступны для урбанизированного населения развитых стран. Зарубежные исследователи обратили внимание на актуальный их потенциал при ведение финансовой, производственной деятельности. Среди западных экономистов начало разработки этой тематики положил Э. Шумахер (1973). Среди азиатских исследователей важный вклад сделал тайский монах и философ П. Пайотто.

В имеющихся исследованиях, связывающих религию и экономическую культуру, буддизм как не поощряет к бедности, и не призывает отказу от материальных благ. Его неверно интерпретировать
Inna S. Tarbastayeva

Institute of Philosophy and Law, Siberian Branch, Russian Academy of Sciences, Russian Federation

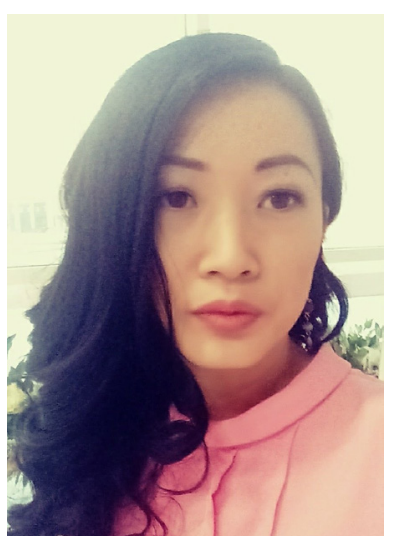

The article actualizes the study of the influence of Buddhist values on the socio-economic development of Tuvan society. Research on economic success in contemporary world has supported the link between Buddhism and economy.

After the spread of Buddhism in the West in the middle of the 20th century, ancient knowledge and practices became available to the urbanized population. Foreign researchers drew attention to their actual potential when conducting financial and industrial activities. Among Western economists, the cornerstone of the idea was laid by E. Schumacher, who published "Small is fine: an economy in which people matter" (1973). Among Asian researchers, an important contribution was made by a Thai monk and philosopher P. Paiotto.

As these and other studies show, Buddhism does not encourage poverty, nor call for a rejection of material wealth. It is incorrect to interpret it as an ascetic religion. Buddhist texts contain direct indications concerning the way of earning money and the meaning of well-being. Modern teachers

Тарбастаева Инна Семеновна - младший научный сотрудник отдела социальных и правовых исследований Института философии и права Сибирского отделения Российской академии наук. Адрес: 630090, Россия, г. Новосибирск, ул. Николаева, д. 8. Тел.: +7 (383) 330-22-40. Эл. адрес: innatarbastaeva@yandex.ru

Tarbastayeva Inna Semenovna, Junior Research Fellow, Department of Social and Legal Studies, Institute of Philosophy and Law, Siberian Branch, Russian Academy of Sciences. Postal address: 8 Nikolayeva St., 630090 Novosibirsk, Russian Federation. Tel.: +7 (383) 330-22-40. E-mail: inna-tarbastaeva@yandex.ru 
как аскетичную религию. В буддийских текстах существуют прямые указания, касающиеся способа зарабатывания денег, смысла благосостояния. Современные учителя также дают советы мирянам относительно экономической активности. Хотя в буддизме практикующие стремятся, прежде всего, к духовным целям - освобождению от страданий, достижению состояния Будды, миряне включены в социальную жизнь и Учение учитывает это.

В буддизме считается, что богатство не способно принести подлинное счастье. Поэтому для практикующего мирянина достижение высокого материального благосостояния не является жизненной целью.

В статье приводятся результаты современных исследований экономистов, психологов нейробиологов, подтверждающих, что эмпирическая корреляция между увеличением доходов и счастьем является незначительно. Приводятся примеры того, как буддийские ценности помогают предпринимателям. Так, в результате веры в закон кармы проявляется большая степень честности при деловом взаимодействии, появляется долгосрочная ориентация на бизнес. Убежденность в непостоянстве помогает принимать рискованные решения, необходимые в предпринимательской деятельности. Актуальность показывают и буддийские практики управления эмоциональными состояниями. Во многих мировых корпорациях (Google, Twitter, Ebay) внедряют программы по практикам осознанности. Это помогает сотрудникам справляться с ежедневным стрессом, усталостью.

Все это побуждает обратиться к обществу тувинцев, для которых буддизм является традиционной религией. Сегодня в Туве повышается престиж буддизма, наблюдается живой интерес со стороны молодежи. Формируется сообщество мирян, получивших современное образование и компетентных в области буддизма. Автор делает вывод, что молодое поколение тувинцев в перспективе сможет применить духовные ценности в практической экономической деятельности.

Ключевые слова: буддизм; буддийские ценности; Тува; тувинцы; Э. Шумахер; возрождение буддизма; молодежь; религиозный фактор; экономическая культура; экономическая деятельность also give advice to laypeople about economic activity. Although in Buddhism practitioners strive, first of all, for spiritual goals - such as liberation from suffering or achieving Buddhahood, laymen are included in social life and have to provide for themselves and their family, which the religious teaching has to account for. Buddhists believe that wealth cannot bring true happiness. Therefore, for a practicing layman, achieving a high level of material well-being is not a life goal. The article presents a summary of the conclusions contemporary economists, psychologists and neurobiologists arrive at, confirming that the empirical correlation between the increase in incomes and happiness is insignificant. Some examples of how Buddhist values help entrepreneurs are also provided. For instance, as a result of faith in the law of karma, there is a greater degree of honesty in business interaction, and a long-term orientation toward doing business (rather than simply enriching oneself) emerges. Feeling that nothing is permanent helps make risky decisions necessary in business. Buddhist practices of managing emotional states also preserve their relevance. Many global corporations (Google, Twitter, Ebay) implement internal programs on awareness practices, which helps employees cope with daily stress and fatigue.

Such conclusions inform the authors' turn to the Tuvan community, where Buddhism is a traditional religion. At present, the prestige of Buddhism is growing in Tuvan society. This is confirmed by the attention the religion receives from the highest-profile public officials of the region, athletes, artists and other influential people in the republic. Among young people, there is a keen interest in the study of Buddhist philosophy. There is also a budding community of laymen who have received modern education and are also competent in the field of Buddhism..

Thus, the Buddhist approach to material values in the Western scientific community is recognized as a manifestation of sanity. The authors make optimistic conclusions that the younger generation of Tuvans in the long term will be able to apply their spiritual values in their economic practices.

Keywords: Buddhism; Buddhist values; Tuva; Tuvans; E. Schumacher; revival of Buddhism; youth; religious factor; economic culture; economic activity

\section{Введение}

Достаточно распространенно мнение, что буддизм призывает к отказу от материальных благ, поощряет бедность. Однако современные исследования и опыт успешных предпринимателей показывают, что буддийские практики способны в значительной степени оказывать влияние на эффективную эконо- 
мическую деятельность. Следует сразу же обозначить, что речь пойдет о мирянах, людях, живущих в светском социуме, но придерживающихся в своих решениях буддийских ценностей, а не о монахах, которые сознательно отказались от активности, связанной с получением материальной прибыли.

Современный период развития буддизма в России характеризуется широким распространением дхарма-центров - мест, где любой желающий может приобщиться к учению. Это формальные или неформальные организации, созданные с целью проведения обучающих занятий по буддийской философии, медитации, а также поддержания общения между заинтересованными в этом людьми. Как правило, дхарма-центры образуют уже квалифицированные наставники, и соответственно они же определяют основные задачи и программу развития организации.

В этом смысле буддизм как образ жизни выходит за границы исключительно монашества, и становится все более доступным для простых жителей, включенных в социальные связи. Многие из них ведут активную предпринимательскую деятельность, и отмечают, что буддийские практики при правильном применении способны повлиять на благосостояние человека и его окружения. Изучая опыт китайских бизнесменов-буддистов, исследователи пришли к выводу, что их религиозные ценности стимулируют предпринимательский риск, а буддизм как система социальных норм и ценностей может играть позитивную роль в предпринимательском поведении и производительности (Zhiyang et al., 2017).

Тувинцы как народ, традиционно исповедующий буддизм, имеют возможность использовать потенциал данного учения для улучшения социально-экономической ситуации в регионе, которая уже долгие годы характеризуется низким качеством жизни, малыми доходами населения, высоким уровнем безработицы и бытовой преступности. В настоящее время в республике идет процесс возрождения буддизма, берущий свое начало со временем визита Далай-ламы XIV в Туву в 1992 г. Тысячи тувинцев смогли вживую услышать учение, увидеть уважаемого духовного учителя. После этого традиционная религия в регионе получила мощный импульс в развитии: стали приезжать квалифицированные тибетские учителя, строятся хурээ (буддийские храмы), возводятся ступы (архитектурно-скульптурные культовые сооружения), проводятся учения ${ }^{1}$, ретриты ${ }^{2}$. Все это дает основания надеяться, что тувинцы смогут применить буддийское наследие для улучшения материального благосостояния сообщества.

В настоящей статье мы рассмотрим, как буддийские ценности способствуют экономической деятельности; какие конкретно идеи, практики признаются

\footnotetext{
${ }^{1}$ Учение - передача квалифицированным мастером знаний буддийской философии; как правило, в виде публичных лекций.

${ }^{2}$ Ретрит - удаление от внешнего мира с целью проведения духовных практик. Ретриты бывают индивидуальные и коллективные.
} 
зарубежными исследователями наиболее благотворными в бизнес-процессах. Также обозначим, почему возможно применение данного позитивного опыта в тувинском сообществе, и какова роль молодежи в этом процессе.

\section{Зарубежные исследования}

Идея о том, что религия влияет на экономическое и социальное развитие, принадлежит М. Веберу. Однако буддизм в понимании философа не приводит к развитию рынка, капиталистической экономики. Нет возможности следовать рациональной деятельности в этом мире, поскольку только те, кто живет без собственности, работы и семьи, блуждают и получают средства к жизни от попрошайничества, могут испытывать мистическое озарение. Поэтому развитие современных капитализма, по его мнению, было невозможным в буддийских культурах, так как не было «капиталистического духа» как в аскетическом протестантизме (Вебер, 2016).

Наиболее значительный поворот в этом вопросе сделал британский экономист Э. Шумахер. В 1973 г. вышел его знаменитый сборник «Малое прекрасно: экономика, в которой люди имеют значение», в котором он излагает впечатления после работы экономическим советником в Юго-Восточной Азии. Он пришел к выводу, что западные экономические модели не подходят для буддийских стран, потому что последние основаны на иной метафизике, и вводит понятие «буддийская экономика» (Шумахер, 2012).

Шумахер утверждает, что современная экономическая наука в погоне за средствами упускает из виду самого человека. Он пишет: «... буддийский образ жизни удивительно разумен: самых скромных средств достаточно для достижения полного благополучия. Но западному экономисту понять это очень трудно. Он привык мерить уровень жизни количеством потребленных за год товаров и услуг, полагая, что человек, потребляющий больше, живет лучше того, кто потребляет меньше. Для буддийского экономиста такой подход абсурден: потребление - не цель, а средство, показателем же уровня жизни является максимальное благополучие при минимальном потреблении» (там же: 54). Экономист отмечает, что «нескончаемая гонка за максимальным потреблением требует огромных усилий и средств, в то время как поддержание образа жизни, нацеленного на оптимальное потребление, куда менее затратно. Поэтому не стоит удивляться тому, что американец подвергается значительно большему стрессу чем, скажем, бирманец, и это несмотря на то, что Бирма, по сравнению с США, почти не использует трудосберегающие технологии» (там же). Кроме того, экономист обосновывает приоритетное развитие малых рабочих единиц перед мега-крупными организациями, созданных для увеличения прибыли; показывает неразумность использования в промышленных масштабах сокращаемых природных ресурсов; осуждает безудержную гонку за материальным обогащением. 
С 1970-х годов концепция Шумахера становится популярной на Западе, особенно среди членов экологических движений. В научном сообществе постепенно признается, что буддийская экономика помогает западным странам решать проблемы чрезмерного потребления, социального дискомфорта и разрушения природы. К настоящему времени существует значительное количество зарубежных работ, посвященных этой тематики. Наиболее известны работы экономистов А. Колина (Colin, 2008), Т. Конеки (Konecki, 2017), Л. Р. Лоя (Loy, 2003), Р. Лэйрада (Layard, 2003: Электр. ресурс, 2005) и других.

Последний крупной работой в этом направлении является коллективный труд под редакцией венгерского экономиста Л. Зсолная «Этические принципы и экономическая трансформация - буддийский подход», где представлены идеи экономистов и бизнес-ученых, занимающихся различными буддийскими традициями (Ethical Principles ..., 2011). Он отмечает, что «эти идеи могут казаться иррациональными или, по крайней мере, наивными для западного разума, который озабочен культивированием желаний и инструментальным использованием мира, однако глубокий экологический и финансовый кризис нашей эпохи вынуждает поиски альтернативных подходов к экономике» (там же: 8).

Важный вклад в раскрытие взаимосвязи буддийских ценностей и экономического развития внесли азиатские исследователи. Так, тайский буддийский монах и философ П. Пайотто в книге «Буддийская экономика: срединный путь для рынка» показывает, что буддийские учения дают глубокое понимание психологии желания и мотивирующих сил экономической деятельности (Payutto, 1994). Японский философ, экономист, банкир С. Иноуэ представил книгу «Введение буддизма в работе. Новый подход к управлению и бизнесу», где обосновывает, что основная задача буддийской экономики - служить сообществу; прибыль же является побочным продуктом. Он выделяет благодарность к другим существам и чувство сожаления о причинении им вреда как важнейшие ее принципы (Inoue, 1997).

\section{Буддизм о богатстве}

Согласно буддизму, как его трактуют исследователи, нет ничего плохого в материальном благополучии. Несмотря на популярный образ буддизма как аскетичного учения, ограничивающего мирские удовольствия, такой подход был фактически опробован и отклонен Буддой, прежде чем он достиг просветления (Payutto, 1994). Идея срединного пути заключается в том числе, и в создании благоприятных условий для жизни и практики, облегчении крайних форм страданий. Буддизм никоим образом не противоречит физическому благополучию (Шумахер, 2012).

Если богатство не стимулирует привязанность и жадность, то обладание им может принести пользу. Известно, что многие из учеников Будды, будучи бога- 
тыми, свободно посвятили большую часть своего имущества поддержке сангхи и уменьшению бедности (Payutto, 1994). Для отдельного взятого индивида материальный достаток также играет важную роль. Так, Чже Цонкапа ${ }^{1}$ в Большом Ламриме ${ }^{2}$ указывает богатство как одно из достоинств, которые проявляются у практика благодаря нравственному образу жизни, и помогают ему продвигаться по пути к освобождению (Цонкапа, 2012: 307).

Крайняя бедность, как правило, для обычных людей сопровождается сильными душевными, физическими страданиями. Невозможность удовлетворить основные жизненные потребности отодвигает за задний план мысли о достижении высшего счастья в буддийском понимании. Возможна навязчивая иллюзии о том, что материальные возможности способны принести полное удовлетворение. Поэтому такое положение в буддизме расценивается как несвободное. Из-за бедности люди могут быть слишком озабочены борьбой за выживание, чтобы делать что-либо для своего собственного духовного совершенства (Payutto, 1994).

Вместе с тем, буддизм призывает довольно осторожно подойти к вопросу о материальном обогащении. Прежде всего, важен честный способ заработка денег, основанный на понимании закона кармы. Во многих буддийских канонических текстах подчеркивается важность чистых средств к существованию (Цонкапа, 2012). Воровство, обман плохи тем, что в результате приведут к потери имущества, ненадежности окружения в будущем, включая последующие жизни. Здесь буддизм позиционирует себя не как догматичная религия, а как основанная на причинно-следственной взаимосвязи доктрина о реальности. Поэтому существует правило, согласно которому некоторые виды деятельности должны быть исключены из способов зарабатывания денег: «... мирянам запрещено заниматься оружием, живыми существами (например, рабами или проституцией), опьяняющими напитками, наркотиками, ядами» (Payutto, 1994: 343).

Далее, буддийские учителя часто говорят о переоценке материальных ценностей, их непомерно завышенной роли в современном мире. Деньги не способны принести подлинное счастье, поэтому система приоритетов выстраивается, исходя из внутренней гармонии: «спокойствие ума, здоровье тела, финансовый достаток» (Буддизм - это наука об уме ..., Электр. ресурс). В то время как

\footnotetext{
${ }^{1}$ Дже Цонкапа (1357-1419) - великий тибетский учитель, основатель буддийской традиции гелуг, которая в настоящее время распространена ряде регионов центральной Азии, в том числе в Туве. Глубоко почитаемый наставник у монголоязычных народов и тувинцев; последние называют его «Богда Бурган». В современных тувинских хурээ празднуют день его рождения и ухода в махапаранирвану. Во время проведения религиозных ритуалов для населения используется его система и его учеников.

${ }^{2}$ Большой Ламрим, или Ламрим Ченмо - это знаменитый труд Дже Цонкапы, представляет собой систематическое руководство, детально описывающее методы духовного развития вплоть до достижения полного Пробуждения в соответствии с учением Будды Шакьямуни. Это один из самых читаемых буддийских текстов в Туве; многие практикующие выстраивают свою систему подготовки согласно Ламриму.
} 
в западном мире градациях этих ценностей происходит в обратном порядке. Одной из причин этого лидер буддистов мира, Его Святейшество Далай-лама XIV видит в недостаточно развитой духовности в индустриальном обществе. «Те тибетцы, которые обладают более обладает более глубоким духовным опытом, - ценят деньги за то, что они дают, но при этом признают, что есть и другие, более важные ценности. - пишет он. - Большинству же людей недостает развитого духовного опыта, и общество в целом придерживается правил, диктуемых деньгами и властью» (Далай-лама XIV о деньгах..., Электр. ресурс).

В идеале субъективное отношение к собственным материальным благам должно исходить из рационального понимания их практической значимости. Привязанность, страстное влечение, одержимое желание накопления признаются в качестве отрицательных разрушающих эмоций, поэтому против таких ментальных состояний в буддийском арсенале имеются целый ряд так называемых «противоядий». Иными словами, проблема не в богатстве, а в привязанности к нему, не наслаждение приятными вещами, а стремление к ним (Шумахер, 2012).

Пайотто пишет: «Богатство не должно становиться одержимостью, причиной беспокойства. Скорее, оно должно быть связано с пониманием его истинных преимуществ и ограничений и то, каким образом оно ведет к личному развитию» (Рayutto, 1994: 42). При этом привязанность оценивается как неблагоприятное состояние ума относительно любых явлений, а не только по отношению к материальным ценностям.

Доктор буддийской философии Геше Джампа Тинлей в публичных лекциях в г. Кызыле часто образно описывает правильное отношение к деньгам, сравнивая их с зимней обувью, которая, безусловно, необходима, однако ее место на нижней полке, а не алтаре, таким образом, показывая роль благосостояния в общей жизненной перспективе. Он советует своим слушателям не слишком радоваться богатству, и не слишком огорчаться из-за бедности; развивать внутреннюю удовлетворённость тем, что есть. И желает одновременного духовного и материального развития будущему молодому поколению. «Наша жизнь коротка, и нам нужно уметь довольствоваться тем, что мы имеем. Голове нужна крыша, телу - удобная одежда, желудку - еда, а для сердца самое главное - это Дхарма», - убежден буддийский мастер (Геше Джампа Тинлей, 2017: 205).

\section{Научные исследования счастья и дохода}

В буддизме говорится, что богатство, как и любой внешний для человека объект, не способно полностью избавить от страданий, и принести подлинное счастье. Деньги способны избавить от крайних форм страданий, но не бессильны избавить нас от когнитивного искажения реальности (неведения), которое считается главной причиной всех бедствий. Поэтому для практикующего ми- 
рянина достижение высокого материального благосостояния не является жизненной целью.

Шумахер пишет: «В то время как материалист в основном интересуется товарами, буддист в основном интересуется освобождением» (Шумахер, 2012: 60). В буддизме, как в любой религиозной системе, существует высшая конечная цель, к которой стремятся практикующие. В данном случае - это освобождения от страдательного сансарического ${ }^{1}$ бытия, достижение истинного покоя нирваны, а также дальнейшего состояния полного пробуждения. Поэтому в этом широком контексте финансовое благополучие представляется как локальный результат щедрости в прошлом, который является желательным, но не крайне необходимым.

Буддийские учителя в лекциях часто подчеркивают, что чем безмятежней ум, тем счастливее человек. Богатство же не приносит спокойствия ума. Современные научные исследования показывают солидарность с буддизмом в этом вопросе. Так, экономисты обнаружили, что эмпирическая корреляция между увеличением доходов и счастьем в лучшем случае является незначительной. Колин пишет: «Исследование счастья последовательно показывает, что, как только достигнут достаточно базовый уровень реальных доходов, дополнительный доход или потребление приносят очень мало дополнительного счастья.... Через некоторое время мы привыкаем к более высокому материальному уровню жизни и считаем это само собой разумеющимся» (Colin, 2008: 208). Другими словами, счастье «возвращается» к базовому уровню.

За последние двадцать лет нейробиологи достигли значительного прогресса в изучении позитивных эмоций, счастья. В лабораториях проводятся обширные исследования уровня серотонина, кровотока, поглощения кислорода, электрической активности в разных частях головного мозга. Появились работы, посвященные объективным доказательствам субъективного благополучия (Davidson, 2000, 2004; Layard, 2005). Колин пишет: «Счастье, в принципе, измеряется как кровяное давление» (Colin, 2008: 209). Это показывает, что ученые серьезно подходят к категории «счастье». Ведущий экономист по вопросам труда Лондонской школы экономики Р. Лейард, автор знаменитой книги «Счастье: уроки новой науки» (Layard, 2005) пришел к выводу, что буддийские психологические практики медитации, развивающие сострадательную природу, имеют под собой весомые основания (Layard, 2003: Электр. peсурс, 2005).

В частности, близкие отношения в семье, с друзьями, на работе радуют нас, обеспечивают любовь поддержку, определяют нашу идентичность - наше чувство того, кто мы. «Наконец, и, самое главное, наше счастье, - заключает он, зависит от нашего внутреннего я и нашей философии жизни (Layard, 2005: 73).

${ }^{1}$ В буддизме считается, что существа, находящиеся в состоянии неведения, непрерывно страдают; такое существование называется сансарой. 
Эти слова созвучны с мнением Его Святейшества Далай-ламы XIV: «главное счастье - это ментальное счастье, покой ума. Это состояние поможет преодолеть и неприятные телесные ощущения. Поэтому недостаточного одного материального прогресса - необходимо работать с умом, сознанием, независимо от того, буддист вы или нет» (Липич, 2016: Электр. ресурс).

\section{Позитивное влияние буддийских цеенностей на бизнес}

Исследователи, изучая влияние буддийских ценностей на экономику, приходят к выводу, что они положительно влияют на производственные процессы, поскольку помогают предпринимателям проявлять долгосрочную ориентацию в процессе разработки стратегии.

В особенности отмечается идея кармы, которая предполагает, что всякий поступок будет иметь последствия в будущем, включая следующие жизни. Считается, что рано или поздно поступки принесут соответствующие результаты; кармические отпечатки не исчезают, и придется испытать их потенциал. В результате действия субъекта в большей степени ориентированы на благополучие в будущем, чем на краткосрочный локальный результат. Отсюда возникает большая степень честности во взаимодействии субъекта со своими сотрудниками и клиентами, и формирует отношения доверия, положительно влияет на репутацию фирмы (Шумахер, 2012; Marques, 2012).

Буддийская концепция непостоянства, указывающая на временный характер всех явлений, также показывает свою актуальность в рыночных отношениях, способствует выработки адаптационных механизмов. Так, солидарность с этой идеей помогает принимать рискованные решения, необходимые в предпринимательской деятельности, и дает установку не привязываться к жестким, устойчивым моделям действий. Он убежден, что стратегия, основанная на буддийском понимании непостоянства, оказывается более выигрышной с экономической точки зрения (Zhiyang, 2011). Как пишет В. М. Лоренс: «Компании зависят от таких аспектов своей деятельности, как инновации, обновление и ребрендинг продуктов, а также от способности найти пути сохранения конкурентоспособности на глобальном рынке и удовлетворять изменяющиеся потребности клиентов. Именно поэтому из всех концепций буддизма теория изменчивости находит самое широкое понимание в деловом мире» (Далай-лама XIV, Майзенберг, 2010: 38).

Таким образом, буддийская концепция непостоянства формирует более гибкое экономическое мышление, что позволяет приспосабливаться к изменениям и сохранять внутреннее спокойствие.

Экономисты отмечают положительные преимущества нравственного образа жизни, еще одного краеугольного камня буддийской практики. Привер- 
женность к обетам мирянина - отказ от убийства, воровства, лжи, прелюбодеяния, алкоголя и наркотиков, безусловно, создает в сообществе атмосферу доверия (Schwartz, 2004). Аналогичную пользу способны принести сострадание и любовь, культивируемые в буддийских практиках. Справедливо отмечает Пайотто, что если сообщество небезопасно, если есть угроза насилия и дороги небезопасны для путешествий, тогда очевидно, что будут сложно с привлечением инвестиций, туристы не захотят туда идти, и экономика пострадает (Рayutto, 1994).

Буддийские практики управления эмоциональными состояниями также доказали свою актуальность. Мы наблюдаем, как в западном обществе возрастает интерес к медитации, созерцательным практикам. Отчасти это вызвано высоким уровнем стресса, тревожности из-за современного динамичного образа жизни. Представители бизнеса, участники сложных деловых связей все чаще признаются, что буддийские практики управления эмоциональными состояниями, в особенности средства борьбы с гневом, раздражительностью, положительным образом влияют на уровень возбужденности во время делового процесса. Это позволяет повысить личную эффективности для руководителей и сотрудников, увеличить удовлетворенность от работы.

Во многих корпорациях начали устраивать практики осознанности. Так, Google разработал и ввел собственную программу медитации «Поиск внутри себя» («Search InsideYourself»), которую ежегодно посещают две тысячи сотрудников компании. Этот эксперимент оказался настолько удачным, что компания создала версии начального уровня - «Управление вашей энергией». Поисковый гигант также создал лабиринт для ходьбы по медитации.

Основатель и председатель знаменитой американской компании в области интернет-магазинов еВау Пьер Омидьяр высоко ценит буддийскую мудрость. Выступая вместе с Туптен Джинпой, переводчиком с английского у Его Святейшество Далай-ламы в 2013 г. на конференции «Мудрость 2.0.» (г.Сан-Франциско, США), он объяснил успех сайта-аукциона человеческой добродетелью и доверием к совершенно незнакомым людям (Найдется Ничто: ..., Электр. ресурс). Также для своих сотрудников Омидьяр оборудовал комнаты для медитации со специальными подушками и цветами (Rayder, 2013: Электр. pecypc).

Эван Уильямс, один из основателей Твиттера, организовал регулярные сеансы медитации в своем новом предприятии - Obvious Corporation (Rayder, 2013: Электр. ресурс).

Конеки убежден, что в современные дни капитализм нуждается в большей релаксации, концентрации и спокойствии. Он пишет: «Тишина, создаваемая во время медитации, помогает более четко видеть мысли .... Благодаря созерцанию может быть достигнута более целостная картина того, что что хорошо, а что плохо для бизнеса и организаций» (Konecki, 2017: 13). 


\section{Перспективы исследования}

В российском научном сообществе данная тематика нашла отражение в ряде публикаций. Так, М. С. Уланов и Г. В. Уланова также обосновывают экономический потенциал буддийской культуры, и ее влияние на экономическую жизнь в целом, рассматривая идеи Э. Ф. Шумахера (Уланов, Уланова, 2014). Социолог Т. Б. Бадмацыренов и В. А. Родионов анализируют экономические институты буддийских сообществ, способы и механизмы ресурсного обеспечения их потребностей (Бадмацыренов, Родионов, 2014). Примечательно, что указанные авторы представляют регионы, традиционно исповедующие буддизм - Калмыкию и Бурятию.

Чрезвычайно актуальна данная работа и для Тувы. В том числе и потому, что молодое поколение от 18 до 30 лет проявляет интерес к изучению буддизма.

Ведущий тувинский религиовед О. М. Хомушку, говоря о том, что в настоящее время в республике наблюдается возрождение традиционной религии буддизма, отмечает увеличение числа молодежи, посещающих соответствующие лекции и мероприятия (Хомушку, 2015). Добавим, что заинтересованность выражается и в создании неформальных молодежных организаций, объединяющих желающих глубже изучать данное учение. Так, молодежное буддийское движение «Субедей» во главе с монахом Шолбаном Иргитом, прошедшего базовую подготовку в индийском монастыре Гоман дацан, объединяет около двухсот человек. В основном это студенты, обучающиеся в таких крупных российских городах, как: Красноярск, Благовещенск, Новосибирск, Абакан, Москва, Омск, Улан-Удэ. Сам лидер движения проживает в Туве, но регулярно проводит онлайн трансляции, освящая те или иные положения учения, в том числе и ориентируя слушателей на правильный образ жизни.

Еще одним объединением можно считать учеников Геше Джампа Тинлея. Наиболее активная часть этого объединения составляет около сорока человек. Это уже работающая кызылская молодежь, которая на базе дхарма-центра «Манджушри» организовала систему обучения, преимущественно по темам Ламрима. Помимо еженедельных занятий данная группа выезжает на коллективные, индивидуальные ретриты, которые проводятся на территории Байкальского медитационного центра (с. Заречье), где успешно выступает в традиционных буддийских диспутах с представителями других российских центров, созданных под руководством наставника Геше Джампа Тинлея. Также самостоятельно проводит городские ретриты по подготовительным практикам нендро.

Другими словами, в тувинском сообществе формируется прослойка населения среди мирян, компетентная в области буддийской философии. Уровень их просвещённости в значительной степени отличается от знаний старшего советского поколения: они глубже разбираются в основных положениях Учения, лучше ориентируются в терминологии, имеют общее представление о су- 
тре и тантре. Этому способствует доступность буддийской литературы, в том числе на русском языке, наличие высоко квалифицированных наставников. А самое главное: наблюдается иной подход к буддизму как системе целостного мировоззрения, а не только как к обрядовым практикам. В этом заключается принципиальное различие в восприятии населения буддизмом различными поколениями.

Более того, можно сказать, что в молодежной среде существует некоторый модный тренд на буддизм как высокие духовные знания. Авторитетные спортсмены, борцы, популярные поп-исполнители, артисты, посещая лекции учителей, транслируют значимость этих событий в публичное пространство. Периодическое присутствие главы региона Шолбана Кара-оола на учениях, в частности Геше Джампа Тинлея, и его традиционная благодарственная речь за помощь в возрождении религии в республике, однозначно повышают престиж буддизма в глазах населения (Геше Джампа Тинлей выступит ..., Электр. ресурс) Создается определенный символический капитал, который набирает силу, и, безусловно, не может не влиять на этносоциальные процессы, протекающие в регионе.

Учитывая это, исследователям своевременно задаться вопросами: влияют ли буддийские ценности на экономическое мышление; если да, то каким образом, как применять данное знание в тувинском сообществе. Важно понять, может ли буддизм как традиционная религия тувинцев, помочь сотворить в регионе экономическое чудо, вывести качество жизни на новый качественный уровень.

Хотя зарубежные исследования показывают востребованность этих знаний в современных экономических отношениях на уровне передовых мировых корпораций, мы полагаем, что в тувинском сообществе не до конца осознается этот актуальный потенциал в рыночных взаимоотношениях. Чаще он представляется как традиционные знания, способствующие поддержанию этнической идентичности, распространению духовных ценностей, духовной помощи. Однако возрастающий интерес молодежи к буддизму дает основания полагать, что уже сейчас имеются практики, всерьез полагающиеся на буддийские знания при принятии финансовых решений, деловых контактов.

\section{Заключение}

Современные исследования показывают, что буддийские практики способны в значительной степени оказывать влияние на экономическую деятельность, способствуя ее эффективности. В этом смысле возможно тувинскому обществу требуется новый взгляд на буддизм, в том числе, и как на источник знаний, ориентиров и вдохновения для улучшения материального благосостояния в регионе. Сочетание предпринимательских навыков и буддийских ценностей в 
тувинском сообществе нам видится желательной перспективой, зримым идеалом в будущем. И особую роль в этом процессе предстоит сыграть молодому поколению, обладающему актуальными знаниями в области бизнеса и стремящемуся к глубокому пониманию самого учения.

\section{СПИСОК ЛИТЕРАТУРЫ}

Бадмацыренов Т. Б., Родионов В. А. (2014) Социология экономики буддизма: концептуальный анализ // Вестник Бурятского государственного университета. Педагогика. Филология. Философия. № 14-2. С. 49-54.

Буддизм - это наука об уме (2012) [Электронный ресурс] // Тува.Азия. 6 июня. URL: https://www.tuva.asia/news/asia/4892-tinley50.html (дата обращения: 19.03.2018).

Вебер, М. (2016) Хозяйство и общество: очерки понимающей социологии / пер. с нем. под ред. Л. Г. Ионина. М.: Изд. дом Высшей школы экономики. 448 с.

Геше Джампа Тинлей (2017) Буддийские наставления о семье / под ред. Ч. Ондара; устный перевод с англ. Б. Дондокова, А. Морозова. Новосибирск : ОО «Издательство Дже Цонкапа». 346 с.

Геше Джампа Тинлей выступит с лекциями в каждом районном центре Тувы (2013) [Электронный ресурс] // Официальный портал Республики Тыва. 28 марта. URL: http://gov.tuva.ru/press_center/news/society/1768/?sphrase_id=36426 (дата обращения: 19.03.2018).

Далай-лама XIV о деньгах (2018) [Электронный ресурс] // Портал: религия и деньги. 2 февраля. URL: http://денга.pф/dalaj-lama-xiv-o-dengax/ (дата обращения: 19.03.2018).

Далай-лама XIV, Майзенберг, Л. (2010) Путь истинного лидера. М.: Эксмо. 297 с.

Липич, О. (2016) Далай-лама призвал к заботе о других и к размышлению о пустоте [Электронный ресурс] // РИА Новости. 11 октября. URL: https://ria.ru/ religion/20161011/1478989105.html (дата обращения: 19.03.2018).

Найдется Ничто: взрыв осознанности в IT (NYTimes) (2014) [Электронный ресурс] // Дмитрий Соловьев: блог о цифровом детоксе. 23 мая. URL: http://www. soloveev.ru/wisdomit/ (дата обращения: 19.03.2018).

Уланов, М. С., Уланова, Г. В. (2014) Э. Ф. Шумахер и концепция буддийской экономики // Вестник Калмыцкого государственного университета. № 3 (23). C. $108-112$.

Хомушку, О. М. (2015) Возрождения буддизма в Туве: от прошлого к настоящему // Религия в изменяющемся мире: сборник научных статей / отв. ред. Э. А. Николаев. Улан-Удэ: Издательство Бурятского госуниверситета. 188 с. 
Цонкапа, Д. (2012) Большое руководство к этапам пути Пробуждения / пер. с тиб. СПб.: Изд-е А. Терентьева. Изд. 4-е, доп. 786 с.

Шумахер, Э. (2012) Малое прекрасно. Экономика, в которой люди имеют значение / пер. с англ. Д. Аронсона. М.: Изд-во ВШЭ. 352 с.

Colin, A. (2008) Happiness and Economics: A Buddhist Perspective // Society and Economy. № 29. P. 201-222.

Davidson, R. (2000) Affective Style, Psychopathology and Resilience: Brain Mechanisms and Plasticity // American Psychologist. № 55. P. 1196-1214. DOI: 10.1037/0003 - 066X.55.11.1196

Davidson, R. (2004) Well-being and Affective Style: Neural Substrates and Biobehavioural Correlates // Philosophical Transactions of the Royal Society (London). № 359. P. 1395-1411. DOI: 10.1098/rstb.2004.1510

Ethical Principles and Economic Transformation - A Buddhist Approach (2011) Ed. L. Zsolnai / Issues in Business Ethics. Vol. 33. 213 p. DOI: 10.1007/978-90-4819310-3

Inoue, S. (1997) Putting Buddhism to work. A new approach to management and business. Tokyo, New York, London: Kodansha International Ltd. 131 p.

Konecki, K. T. (2017) Contemplation for Economists. Towards a Social Economy Based on Empathy and Compassion // Economics and Sociology. № 10 (3). pp. 11-24. DOI: 10.14254/2071-789X.2017/10-3/1

Laszlo, Z. (2011) Why Buddhist Economics? Ethical Principles and Economic Transformation - A Buddhist Approach. Ed. L. Zsolnai / Issues in Business Ethics. Vol. 33, pp. 3-21.

Layard, R. (2005) Happiness: Lessons from a new science. London: Penguin Press. $310 \mathrm{p}$.

Loy, D. R. (2003) The Great Awakening. A Buddhist Social Theory. Somerville: Wisdom Publication Inc. 228 p.

Marques, J. (2012) Consciousness at work: A review of some important values, discussed from a Buddhist perspective // Journal of Business Ethics. № 105 (1). pp. 27-40. DOI: 10.1007/s10551-011-0932-8

Payutto, P. A. (1994) Buddhist economics: A Middle Way for the market place. Bangkok: Buddhadhamma Foundation. 99 p.

Ryder, B. (2013) The mindfulness business. Western capitalism is looking for inspiration in eastern mysticism [Электронный ресурс] // The Economist. № 16. URL: https://www.economist.com/news/business/21589841-western-capitalismlooking-inspiration-eastern-mysticism-mindfulness-business (дата обращения: 15.03.2018). 
Schwartz, B. (2004) The Paradox of Choice: Why More is Less. New York: Harper Collins. 304 p.

Zhiyang, L., Zuhui, X., Zhao, Z., Yong, L. (2017) Buddhist entrepreneurs and new venture performance: The mediating role of entrepreneurial risk-taking // Small Business Economics. № 4. P. 1-14. DOI: /10.1007/s11187-017-9981-4

Дата поступления: 15.03.2018 г.

\section{REFERENCES}

Badmatsyrenov, T. B. and Rodionov, V. A. (2014) Sotsiologiya ekonomiki buddizma: kontseptual'nyi analiz [Sociology of economics in Buddhism: a conceptual analysis]. The Buryat State University Bulletin, no. 14-2, pp. 49-54. (In Russ.).

Buddizm - eto nauka ob ume [Buddhism is the science of the mind] (2012) Tuva. Asia, 6 June [online] Available at: https://www.tuva.asia/news/asia/4892-tinley50. html (access date: 19.03.2018). (In Russ.)

Weber, M. (2016) Hozyaistvo i obshchestvo: ocherki ponimayushchei sociologii [Economy and Society: Essays on Understanding Sociology] / transl., ed. by L. G. Ionin. Moscow, High School of Economics. 448 p. (In Russ.)

Geshe Dzhampa Tinlei (2017) Buddiiskie nastavleniya o sem'e [Buddhist instructions about the family]. Novosibirsk, Dzhe Conkapa. 346 p. (In Russ.)

Geshe Dzhampa Tinlei vystupit s lektsiyami v kazhdom raionnom centre Tuvy [Geshe Jampa Tinley will give lectures in every district center of Tuva] (2013) Ofitsial'nyi portal Respubliki Tyva, 28 March [online] Available at: http://gov.tuva.ru/ press_center/news/society/1768/?sphrase_id=36426 (access date: 19.03.2018). (In Russ.)

Dalai-lama XIV o den'gakh [The Dalai Lama on money] (2018). Portal: religiia $i$ den'gi [online] Available at: http://денга.pф/dalaj-lama-xiv-o-dengax/ (access date: 19.03.2018). (In Russ.).

Dalai-lama XIV and Muyzenberg, L. van den (2010) Put' istinnogo lidera [The leader's way]. Moscow, Ecksmo. 297 p. (In Russ.).

Lipich, O. (2016) Dalai-lama prizval k zabote o drugikh i k razmyshleniyu o pustote [The Dalai Lama called for caring for others and meditating on emptiness]. RIA Novosti, 11 October [online] Available at: https://ria.ru/religion/20161011/1478989105. html (access date: 19.03.2018). (In Russ.).

Naidetsya Nichto: vzryv osoznannosti v IT (NYTimes) [There is Nothing to be found: an explosion of awareness in IT] (2014). Dmitrii Solov'ev: blog o tsifrovom detokse, 23 May [online] Available at: http://www.soloveev.ru/wisdomit/ (access date: 19.03.2018). (In Russ.). 
Ulanov, M. S. and Ulanova, G. V. (2014) E. F. Shumaher i konceptsiya buddijskoi ekonomiki [E. F. Schumacher and Buddhist economics concept]. Bulletin Kalmyk State University, no. 3 (23), pp. 108-112. (In Russ.).

Homushku, O. M. (2015) Vozrozhdeniya buddizma v Tuve: ot proshlogo k nastoyashchemu [Revivals of Buddhism in Tuva: from past to present]. In: Religiya $v$ zmenyayushchemsya mire [Religion in a changing world]: A collection of scientific articles, ed. by A. Nikolaev. Ulan-Ude, Izdatel'stvo Buryatskogo gosuniversiteta.188 p. (In Russ.).

Conkapa,D. (2012) Bol'shoe rukovodstvo k ehtapam puti Probuzhdeniya [A great guide to the stages of the path to Awakening]. Transl. from Tib. St. Petersburg. A. Terent'ev Publ. 4nd ed. 786 p. (In Russ.).

Schumacher, E. F. (2012). Maloe prekrasno. Ekonomika, v kotoroi liudi imeiut znachenie [Small Is Beautiful: A Study of Economics As If People Mattered], transl. by D. O. Aranson. Moscow, High School of Economics. 352 p. (In Russ.).

Colin, A. (2008) Happiness and Economics: A Buddhist Perspective. Society and Economy, no. 29, pp. 201-222.

Davidson, R. (2000) Affective Style, Psychopathology and Resilience: Brain Mechanisms and Plasticity. American Psychologist, no. 55, pp. 1196-1214. DOI: 10.1037/0003 - 066X.55.11.1196

Davidson, R. (2004) Well-being and Affective Style: Neural Substrates and Biobehavioural Correlates. Philosophical Transactions of the Royal Society (London), 359, pp. 1395-1411. DOI: 10.1098/rstb.2004.1510

Inoue, S. (1997) Putting Buddhism to work. A new approach to management and business. Tokyo, New York, London: Kodansha International Ltd. 131 p.

Konecki, K. T. (2017) Contemplation for Economists. Towards a Social Economy Based on Empathy and Compassion. Economics and Sociology, no. 10 (3), pp. 11-24. DOI: 10.14254/2071-789X.2017/10-3/1

Laszlo, Z. (2011) Why Buddhist Economics? Ethical Principles and Economic Transformation - A Buddhist Approach. Issues in Business Ethics, vol. 33, pp. 3-21.

Layard, R. (2005) Happiness: Lessons from a new science. London, Penguin Press. $310 \mathrm{p}$.

Loy, D. R. (2003) The Great Awakening. A Buddhist Social Theory. Somerville, Wisdom Publication Inc. $228 \mathrm{p}$.

Marques, J. (2012) Consciousness at work: A review of some important values, discussed from a Buddhist perspective. Journal of Business Ethics, no. 105(1), pp. 27-40. DOI: 10.1007/s10551-011-0932-8 
Payutto, P.A.(1994) Buddhist economics: A Middle Way for the market place. Bangkok, Buddhadhamma Foundation. 99 p.

Ryder, B. (2013) The mindfulness business. Western capitalism is looking for inspiration in eastern mysticism. The Economist, no. 16 [online] Available at: https:// www.economist.com/news/business/21589841-western-capitalism-lookinginspiration-eastern-mysticism-mindfulness-business (access date: 15.03.2018).

Schwartz, B. (2004) The Paradox of Choice: Why More is Less. New York, Harper Collins. 304 p.

Zhiyang, L., Zuhui, X., Zhao, Z. and Yong, L. (2017) Buddhist entrepreneurs and new venture performance: The mediating role of entrepreneurial risk-taking. Small Business Economics, no. 4, pp. 1-14. DOI:/10.1007/s11187-017-9981-4

Submission date: 15.03 .2018$.

\section{Для циитирования:}

Тарбастаева И. С. Буддийские ценности как возможная экономическая детерминанта развития тувинского общества [Электронный ресурс] // Новые исследования Тувы. 2018, № 2. URL: https://nit.tuva.asia/nit/article/view/772 (дата обращения: дд.мм. гг.). DOI: $10.25178 /$ nit.2018.2.5

\section{For citation:}

Tarbastayeva I. S. Buddhist values as a potential economic determinant in the development of Tuvan society. The New Research of Tuva, 2018, no. 2 [on-line] Available at: https://nit.tuva.asia/nit/article/view/772 (accessed: ...). DOI: 10.25178/nit.2018.2.5 